\title{
EL PROBLEMA CON LA POESÍA (SELECCIÓN)
}

\author{
Por Billy Collins \\ (trad. de R.E. Toledo)
}

\section{Tú, LECTOR}

Me pregunto cómo te vas a sentir cuando te enteres que yo escribí esto, y no tú que fui yo el que se levantó temprano para sentarse en la cocina y con la pluma mencionó

las ventanas empapadas de lluvia, las hiedras del papel tapiz, y al pez dorado dando vueltas en su pecera.

Voltea hacia un lado, anda, muérdete el labio y arranca la página pero, escucha - era solo una cuestión de tiempo

antes de que uno de los dos

se diera cuenta de las velas sin prender y el reloj resonando en la pared.

Además de eso, nada pasó esa mañanauna canción en la radio, un auto silbando al pasar por la calle, afuera- 
y yo estaba pensando acerca del salero y el pimentero que estaban parados juntos sobre el mantelito.

Me preguntaba si ya serían amigos después de todos estos años o si todavía serían unos extraños

como tú y yo que somos conocidos y desconocidos al mismo tiempo-

yo en esta mesa con un plato con peras, tú recargado en el marco de una puerta en algún lugar cerca de las hortensias, leyendo esto.

\section{LUNES}

Los pájaros están en sus árboles,

el pan está en el tostador,

y los poetas en sus ventanas.

Están en sus ventanas

en cada sección de la mandarina tierralos poetas chinos mirando la luna, los poetas americanos observando los listones rosas y azules del crepúsculo.

Los oficinistas están en sus escritorios, los mineros abajo en sus minas, y los poetas mirando por sus ventanas tal vez con un cigarro, una taza de té, y quizás hasta una camisa de franela o una bata de baño estén involucradas. 